\title{
AUDIT SISTEM INFORMASI PADA DINAS PERPUSTAKAAN DAN KEARSIPAN KOTA SALATIGA MENGGUNAKAN FRAMEWORK COBIT 4.1 DOMAIN MONITOR AND EVALUATE
}

\author{
Rivaldo Patawala $^{\left({ }^{D 1}\right)}$ dan Augie D Manuputty ${ }^{\left(D^{2}\right)}$ \\ ${ }^{1,2}$ Sistem Informasi, Fakultas Teknologi Informasi, Universitas Kristen Satya Wacana \\ ${ }^{1,2}$ Jl. Blotongan, Sidorejo Lor, Sidorejo, Kota Salatiga, Jawa Tengah 50714 \\ Email: 682016070@ @tudent.uksw.edu ${ }^{1)}$,augie.manuputty@uksw.edu ${ }^{2)}$
}

\begin{abstract}
ABSTRAK
Dinas Perpustakaan dan Kearsipan Kota Salatiga merupakan instansi pemerintah penyedia sumber informasi, yang mana pengoperasiannya menggunakan peranan TI. Senayan Library Management System (SLiMS) adalah sistem informasi yang digunakan dalam menjalankan bisnis proses perusahaan. Sistem ini mempermudah staf menjalankan tugas dan tanggung jawabnya dalam melayani kebutuhan anggota Perpustakaan seperti peminjaman, pengembalian serta menentukan denda keterlambatan pengembalian buku. Namun, proses pemantauan rutin terhadap SLiMS dilakukan hanya pada hardware dan server. Tidak ada pemantauan yang di lakukan pada software, pemantauan dilakukan hanya pada saat diperlukan atau terjadi masalah. Hal ini mengakibatkan munculnya masalah pada sistem. Control Objective for Information and related Technology (COBIT) 4.1 merupakan kerangka kerja dari best of practices manajemen teknologi informasi yang membantu organisasi untuk memaksimalkan kinerja TI, serta dapat membantu mengelola risiko dan masalah teknis dalam organisasi. COBIT 4.1 digunakan untuk mengukur level kedewasaan dalam proses TI dan mengukur kesesuaian antara kebutuhan perusahaan dan tujuan TI dalam organisasi. Penelitian ini menggunakan framework COBIT 4.1 domain ME untuk menganalisa kinerja sistem informasi pada Dinas Perpustakaan dan Kearsipan Kota Salatiga. Hasil penelitian menunjukkan bahwa ME1 berada di level 2,5 (Repeatable but Intuitive), ME2 berada di level 3,2 (Defined Process), ME3 berada di level 2,4 (Repeatable but Intuitive), ME4 berada di level 4,5 (Managed and Measurable). Dalam hal ini Dinas Perpustakaan dan Kearsipan Kota Salatiga perlu memberikan perhatian dan penanganan khusus pada faktor-faktor yang mempengaruhi proses pemantauan SLiMS, sehingga sistem dapat di operasikan secara maksimal, serta meningkatkan kapasitas karyawan dalam penggunaan TI khususnya skills dalam mengoperasikan SLiMS, sehingga kemampuan penanggung jawab TI dapat mengimbangi perkembangan teknologi.
\end{abstract}

Kata Kunci: Audit, System Information, Frameworks COBIT 4.1, Monitor and Evaluate, Maturity Level, SLiMS

\section{PENDAHULUAN}

Teknologi Informasi (TI) berkembang dengan pesat dan menguasai semua bidang kehidupan. Salah satunya adalah penerapan TI dalam dunia bisnis yang digunakan sebagai alat bantu dalam usaha memenangkan persaingan. Hal ini membuat TI menjadi bagian yang tidak terpisahkan dari sistem operasional perusahaan saat ini (Maghfiroh, Murahartawaty and Mulyana, 2016). Perkembangan TI yang cepat dalam membantu sebuah perusahaan atau institusi, harus diimbangi dengan adanya proses evaluasi atau audit sistem informasi terhadap penggunaan TI tersebut, sehingga dapat meminimalisir risiko dan kerugian terhadap perusahaan/organisasi. TI memberikan peluang dalam proses transformasi dan peningkatan produktivitas dalam bisnis proses. Pemanfaatan TI sebagai pendukung dalam mencapai visi dan misi organisasi/perusahaan. Dengan demikian diperlukan sebuah sistem monitor dan evaluasi yang efektif dan efisien. Audit sistem informasi dibutuhkan untuk menjaga keamanan sistem informasi sebagai aset organisasi, dan untuk mempertahankan integritas informasi yang disimpan dan dikelola untuk meningkatkan keefektifan penggunaan TI serta mendukung efisiensi dalam organisasi/perusahaan.

Dinas Perpustakaan dan Kearsipan kota Salatiga telah menggunakan peranan TI dalam proses operasional organisasi. Hal ini bertujuan sebagai usaha dalam meningkatkan kemampuan sistem informasi yang dapat melayani kebutuhan pengelolaan perpustakaan yang holistik dan terintegrasi. Dalam mencapai hal tersebut Dinas Perpustakaan dan Kearsipan kota Salatiga menggunakan sistem informasi SLiMS (Senayan Library Automation System). Dinas Perpustakaan dan Kearsipan Kota Salatiga telah menggunakan SLiMS sejak Tahun 2010 dan melakukan upgrade secara bertahap. Hal ini bertujuan memenuhi kebutuhan pengguna. Saat ini Dinas Perpustakaan dan Kearsipan Kota Salatiga menggunakan SLiMS 7 (Haullusy and Manuputty, 2019). Penggunaan sistem informasi pendukung dalam mendukung pelayanan pada Dinas Perpustakaan dan Kearsipan kota Salatiga memerlukan pengelolaan sistem yang baik untuk mendukung proses pelayanan pengguna. Oleh 
sebab itu diadakan evaluasi atau penilaian terhadap penerapan teknologi dalam perusahaan. Audit Sistem Informasi dilakukan dengan tujuan untuk mengetahui sejauh mana kinerja SI/TI, SDM perusahaan, dan untuk mengetahui tingkat kematangan penggunaan TI dalam perusahaan, sehingga penggunaan teknologi informasi dalam perusahaan dapat berperan secara maksimal. Pada penelitian ini menggunakan Control Objective for Information and related Technology (COBIT) 4.1 bukan COBIT 5, karena penerapan tingkat kematangan masih menggunakan Capability Maturity Level bukan Process Maturity Level pada COBIT 5 sehingga penggunaan COBIT 4.1 lebih optimal daripada COBIT 5 dan merupakan kerangka kerja yang representatif dan mencakup semua permasalahan perencanaan, penerapan, operasional dan pemantauan terhadap proses jalannya seluruh proses bisnis perusahaan (Rahayu and Wijaya, 2020).

Audit sistem informasi bertujuan untuk menganalisa dan mengevaluasi apakah sistem sudah beroperasi sesuai dengan prosedur agar dapat mencapai tujuan dari perusahaan/organisasi. Organisasi yang dimaksud adalah Dinas Perpustakaan dan Kearsipan Kota Salatiga khususnya pada bagian Sirkulasi. Dalam melakukan audit sistem diperlukan standar yang jelas, sebagai acuan dasar TI. Kerangka kerja sistem audit yang umum digunakan adalah COSO, COBIT, ISO, dan lainlain (Rumere, Tanaamah and Sitokdana, 2020). Kerangka kerja yang digunakan dalam melakukan penelitian ini adalah Framework COBIT 4.1 domain Monitor and Evaluate (ME) dengan alasan proses TI yang harus diawasi dan dinilai kelayakannya pada sistem informasi secara regular dan berkala menurut standar COBIT 4.1, yakni mengawasi dan mengevaluasi kinerja TI, mengawasi dan mengevaluasi kontrol internal, memastikan pemenuhan terhadap kebutuhan eksternal dan menyediakan tata kelola TI (Taslihudin, 2016). Oleh sebab itu, penulis menjadikan beberapa penelitian sebelumnya sebagai bahan acuan komparatif, antara lain:

Penelitian yang dilakukan oleh Jourdano dan tim, dengan judul "Audit Sistem Informasi Menggunakan Framework COBIT 4.1 (Dengan Domain Monitor and Evaluate) Pada PT. Samudera Indonesia Tbk ". Peneliti menggunakan Framework Cobit 4.1 domain ME dalam penelitian tersebut. Tujuan penelitian adalah untuk mengukur tingkat kematangan dari TI perusahaan berdasarkan proses monitor, pengelolaan dan sejauh mana perusahaan memenuhi aturan hukum dalam TI yang berlaku. Proses penilaian menunjukkan tingkat kematangan domain ME tergolong domain yang memenuhi prosedur dan standar, dengan hasil perolehan nilai ME1 sebesar 4,04, ME2 3,87, ME3 sebesar 3,74, ME4 sebesar 3,91. Tingkat kematangan TI pada PT. Samudera Indonesia dinilai tergolong kriteria defined, dikarenakan perusahaan menjalankan proses TI sesuai dengan prosedur dan standar yang telah ditentukan, dan sudah disesuaikan dengan model bisnis, strategi dan tujuan bisnis dari perusahaan (Jourdano $d k k$., 2018).
Penelitian Andry dan tim berjudul " Penggunaan COBIT 4.1 Dengan Domain ME Pada Sistem Informasi Absensi (Studi Kasus: Universitas XYZ) ". Fokus penelitian ini adalah proses audit pengawasan dan evaluasi terhadap Sistem Informasi Absensi. Tujuan dari penelitian ini adalah menilai dan mengevaluasi proses kinerja absensi fingerprint apakah beroperasi dengan baik dan efektif menggunakan standar Framework COBIT 4.1 domain ME. Penelitian ini menunjukkan bahwa Universitas XYZ telah menerapkan Framework monitor pada tingkat defined process. Tingkat tersebut ditemukan berdasarkan hasil dari beberapa standar domain yaitu ME1, ME2, ME3, dan ME4 yang telah dioperasikan dan menghasilkan maturity level sebesar 3,4 dengan expected level berada pada tingkat 4 yaitu managed and measurable dan memiliki nilai gap sebanyak 0,6. Hal ini berarti bahwa proses monitor dan evaluasi serta kesimpulan yang dihasilkan dari sistem informasi absensi pada Universitas XYZ sesuai dengan standar Framework COBIT 4.1 (Andry dkk., 2018).

Penelitian dilakukan Marzuki dan tim dengan judul “Audit Tata Kelola Teknologi Informasi Menggunakan Cobit 4.1 Domain Monitoring Evaluasi Pada Perguruan Tinggi Swasta ". Penelitian ini menerapkan Framework COBIT 4.1 domain ME, dimana audit dilakukan secara garis besar pada kondisi kematangan tata kelola TI pada kampus STMIK Bumigora Mataram yang mengacu pada maturity level yang ada pada kerangka kerja COBIT 4.1. Hasil audit tata kelola TI domain ME pada sistem informasi kampus STIMK ditemukan telah memenuhi tingkat kematangan (maturity level) yaitu berada pada level 2,3 (repeat but intuitive). Kondisi ini berdasarkan beberapa kekurangan dalam proses pengoperasian TI, seperti penetapan dokumentasi, dan prosedur yang tidak sempurna, serta tidak tersedianya service level yang di disepakati bersama (Marzuki, Setyanto and Nasiri, 2018).

Berdasarkan penelitian-penelitian terdahulu yang telah dipaparkan di atas, maka penulis akan fokus pada audit sistem informasi menggunakan Framework COBIT 4.1 domain ME pada Dinas Perpustakaan dan Kearsipan kota Salatiga.

\section{RUANG LINGKUP}

Ruang lingkup dalam penelitian ini sebagai berikut:

1. Cakupan masalah pada penelitian ini adalah pengelolaan sistem informasi yang dipakai oleh Dinas Perpustakaan dan Kearsipan kota Salatiga. Oleh sebab penelitian ini berfokus pada audit Sistem Informasi menggunakan Framework COBIT 4.1 pada domain ME.

2. Penelitian ini berfokus pada proses monitor dan evaluasi kinerja TI, menggunakan domain ME pada Framework COBIT 4.1

3. Hasil dari penelitian ini dapat dimanfaatkan dalam mengidentifikasi risiko-risiko yang terjadi dan juga rekomendasi penanganan risiko sesuai dengan Framework COBIT 4.1. 


\section{BAHAN DAN METODE}

Bahan kajian, metode dan tahapan penelitian yang akan dilakukan dalam penelitian ini adalah sebagai berikut:

\subsection{Audit Sistem Informasi}

Audit TI adalah sebuah bentuk audit operasional. Namun, pada saat ini, Audit TI telah menjadi jenis audit yang berfokus dalam peningkatan tata kelola TI. Pengoperasian sumber informasi mengacu pada efektivitas unit fungsional sistem informasi. COBIT sukses mentransformasikan konsep klasik menjadi sebuah sistem informasi yang kerahasiaan informasi terjamin. COBIT adalah sebuah sistem yang efektif dan terpercaya. Hal ini dikarenakan COBIT dapat memonitor pengoperasian sesuai peraturan hukum sistem informasi (Muhammad, J. R., 2021)

Audit sistem informasi adalah sebuah proses pengumpulan dalam rangka menilai bukti - bukti dalam proses penentuan apakah "sistem komputer" dapat menjaga integritas data dan mengamankan aset sehingga tujuan organisasi tercapai secara efektif dan efisien (Kurniawan, Yohanes and Wijaya, 2018).

Audit sistem informasi merupakan proses pengumpulan data dalam rangka mengevaluasi bukti dalam proses menentukan apakah sistem informasi telah menggunakan sistem kontrol internal sesuai standar, dan apakah aset terlindung dan tidak disalahgunakan, serta terjaminnya integritas data, dan sistem informasi yang berbasis pada komputer (Wahono, 2015).

\subsection{COBIT}

COBIT (Control Objectives for Information and Related Technology) merupakan suatu kerangka kerja (framework) bagi pengelola teknologi Informasi. COBIT dikembangkan oleh IT Governance Institute (ITGI) yang merupakan bagian dari Information System Audit and Control Association (ISACA). COBIT disusun oleh ITG pada tahun 1996. Sampai saat ini ada 6 versi COBIT yang diterbitkan, COBIT 1 diterbitkan pada tahun 1996, COBIT 2 tahun 1998, COBIT 3 tahun 2000, COBIT 4.0 tahun 2005, COBIT 4.1 tahun 2007, COBIT 5.0 tahun 2012 dan yang terakhir adalah COBIT 19 diterbitkan tahun 2018 (Rumere, Tanaamah and Sitokdana, 2020).

COBIT 4.1 merupakan kerangka best of practices manajemen TI dengan tujuan menolong organisasi dalam memaksimalkan pendapatan bisnis, serta dapat membantu auditor, user dan manajemen dalam pengelolaan risiko bisnis dan masalah teknis yang terjadi pada organisasi. COBIT merupakan sistem pengukur level kedewasaan (maturity level) TI, dan juga berfungsi dalam mengawasi kesesuaian antara keperluan bisnis dan tujuan TI dalam sebuah organisasi. (Jourdano $d k k$., 2018). Monitor and Evaluate IT perlu dievaluasi secara berkelanjutan dengan tujuan menjaga kualitas dan pemenuhan standar pengendalian. Domain ME IT membutuhkan pengawasan dan pengendalian manajemen dalam organisasi serta evaluasi secara mandiri dilakukan oleh auditor internal dan eksternal (Azizah, 2017). Ditampilkan pada gambar 1, domain ini berhubungan dengan proses monitor dan evaluasi pengelolaan secara internal dalam sebuah organisasi (Asyari and Triana, 2018), domain COBIT yang dipakai peneliti yaitu:

1. ME1 (Monitor and Evaluate IT Performance)

Domain ME1 menekankan pada keperluan proses monitor kinerja manajemen TI yang efektif dalam sebuah perusahaan. Proses ini mencakup penentuan indikator kinerja, merumuskan faktor-faktor yang relevan, serta sistem laporan yang dilakukan secara sistematis dan tepat waktu, serta reaksi yang cepat terhadap penyalahgunaan sistem. Pemantauan dibutuhkan dalam memastikan bahwa pengoperasian sistem dilakukan secara benar berdasarkan aturan dan kebijakan yang berlaku (Jourdano $d k k ., 2018)$.

2. ME2 (Monitor and Evaluate Internal Controls)

Domain ME2 berfokus pada penentuan program pemantauan dan monitoring TI secara internal dalam sebuah perusahaan. Proses ini meliputi monitor dan pelaporan, serta hasil evaluasi diri dan pihak external dari perusahaan. Manfaat utama dari pemantauan dan pengendalian internal adalah untuk menjaga sistem operasi yang efektif dan efisien serta sesuai berdasarkan hukum dan aturan yang berlaku (Jourdano $d k k ., 2018$ ).

3. ME3 (Ensure Compliance External Requirements)

Domain ME3 menekankan perusahaan untuk mengikuti hukum dan peraturan kontrak yang berlaku. Proses ini berfokus pada identifikasi persyaratan yang berlaku, memaksimalkan dan menilai respon, mendapatkan jaminan bahwa aturan telah dipatuhi, serta proses integrasi laporan yang sesuai dengan aturan bisnis TI (Jourdano $d k k$., 2018).

4. ME4 (Provide IT Governance)

Domain ME4 bertujuan menentukan kepastian sebuah perusahaan dalam proses investasi kebutuhan TI berdasarkan strategi bisnis yang diterapkan. Domain ini fokus pada pembentukan kerangka kerja pengoperasian TI yang efisien dengan tujuan memenuhi rencana strategi yang disepakati bersama (Jourdano $d k k ., 2018$ ).

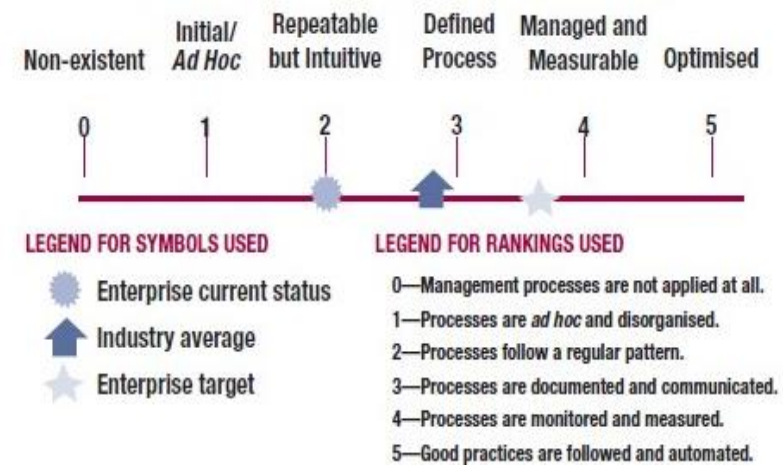

Gambar 1. Maturity Model

(Rahayu and Wijaya, 2020) 
Maturity Model berperan sebagai pengukur kematangan proses TI yang telah diterapkan oleh sebuah perusahaan. Menurut C. T. Harjanto dalam Utomo Dasa Styo Ndaru, tingkat kedewasaan (Maturity Level) COBIT 4.1 bertujuan mengontrol proses TI menggunakan metode penilaian (scoring), sehingga organisasi/perusahaan dapat memonitor dan mengevaluasi proses TI yang dimilikinya (Styo dkk., 2021). Implementasi yang sesuai aturan pada tata kelola TI di lingkungan perusahaan, berfokus pada pemenuhan tiga aspek kematangan (maturity models), yaitu kemampuan, jangkauan, dan kontrol. Dampak dari peningkatan kematangan yaitu mengurangi risiko dan membuat sistem menjadi semakin efisien dan efektif, serta mengurangi risiko dan meningkatkan kuantitas dan kualitas proses yang sesuai standar, serta menjamin efisiensi biaya dalam pengoperasian sumber daya TI. Kemampuan pengoperasian TI yang berfokus pada kerangka kerja COBIT 4.1 mempunyai level kematangan dengan skala level 0 sampai 5 (Jourdano $d k k ., 2018)$.

\subsection{Metode Penelitian}

Metode penelitian yang digunakan dalam penelitian ini adalah pendekatan kualitatif dengan metode deskriptif menurut Mulyana dalam Ditha Prasanti. "Metodologi adalah proses, prinsip, dan prosedur yang dimanfaatkan dalam menganalisa masalah dan mencari jawaban teradapat pertanyaan penelitian" (Prasanti, 2018). Penelitian ini berfokus pada observasi dan wawancara dengan tujuan mengungkap data, fakta,, fenomena, elemen, dan kondisi yang terjadi saat penelitian dilakukan. Observasi di lakukan terhadap TI Dinas Perpustakaan dan Kearsipan kota Salatiga. Peneliti juga mewawancarai narasumber yaitu karyawan yang bekerja pada unit TI di Dinas Perpustakaan dan Kearsipan Kota Salatiga. Dalam penelitian ini peneliti menggunakan domain ME, yang mana domain ini berhubungan dengan kinerja TI yang telah diterapkan pada Dinas Perpustakaan dan Kearsipan kota Salatiga. Penelitian ini terdiri dari beberapa tahap sebagai berikut:

1. Studi Literatur

Tahap ini fokus pada proses analisis teori pada penelitian terdahulu yang relevan yang selanjutnya digunakan sebagai dasar teori dalam penelitian ini.

2. Pengumpulan Data

Menurut Ardianto dalam Susilowati "Metode pengumpulan data adalah metode pengumpulan, pengategorian serta proses analisis data yang tersedia (Susilowati, 2017). Pengumpulan data melalui proses observasi dilakukan pada Dinas Perpustakaan dan Kearsipan kota Salatiga bertujuan mengevaluasi proses bisnis serta penggunaan aplikasi SLiMS. Pengumpulan data juga dilakukan melalui proses wawancara dengan bagian pengelolaan dan pengoperasian aplikasi SLiMS pada Dinas Perpustakaan dan Kearsipan kota Salatiga.

3. Analisis Data

Tahap ini fokus pada proses analisis data menggunakan Framework COBIT 4.1 dengan domain ME.

4. Hasil dan Kesimpulan

Pada tahap ini peneliti akan menulis kesimpulan dan rekomendasi berdasarkan analisis data.

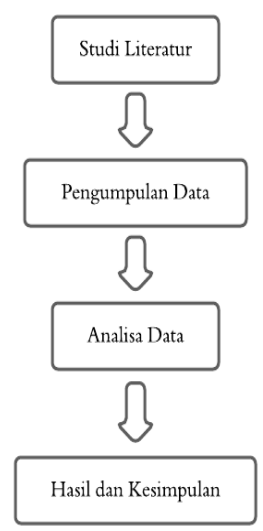

\section{Gambar 2. Diagram Alur Penelitian}

Tahapan penelitian pada gambar 2 dapat dijelaskan sebagai berikut:

1. Tahap pertama, peneliti mengkaji sumber literatur dan pustaka mengenai Framework COBIT 4.1 berfokus pada audit sistem informasi.

2. Tahap kedua, peneliti mengumpulkan data melalui metode observasi dan wawancara pada Dinas Perpustakaan dan Kearsipan kota Salatiga. Peneliti memilih narasumber yaitu karyawan bagian pelayanan pada Dinas Perpustakaan dan Kearsipan Kota Salatiga.

3. Tahap ketiga, melakukan analisis data wawancara yang telah di salin dalam bentuk transkrip. Data wawancara akan digunakan untuk melakukan perhitungan tingkat maturity pada sistem di Dinas Perpustakaan dan Kearsipan kota Salatiga.

4. Tahap terakhir adalah pembuatan laporan hasil audit domain ME dari kerangka kerja COBIT 4.1, serta membuat kesimpulan penelitian.

Peneliti membuat RACI (Responsible, Accountable, Consulted dan Informed) Chart terlihat pada tabel 1, bertujuan menganalisa proses dan fungsi pelayanan sistem yang diinginkan dalam menyelesaikan masalah. RACI menunjukkan tokoh-tokoh yang terlibat dalam sebuah tindakan pada perusahaan dan juga pemerintahan (Rumere, Tanaamah and Sitokdana, 2020). 
Tabel 1. Tabel RACI Chart

\begin{tabular}{|c|c|c|}
\hline RACI & Fungsi/Peran & Responden \\
\hline Responsible & $\begin{array}{c}\text { Memastikan aktivitas } \\
\text { berjalan sesuai rencana. }\end{array}$ & $\begin{array}{c}\text { Kepala } \\
\text { Perpustakaan }\end{array}$ \\
\hline Accountable & $\begin{array}{c}\text { Bertanggungjawab } \\
\text { dalam mengontrol dan } \\
\text { menerima pelaksana } \\
\text { aktivitas. }\end{array}$ & $\begin{array}{c}\text { Pranata } \\
\text { Komputer }\end{array}$ \\
\hline \multirow{3}{*}{ Consulted } & $\begin{array}{c}\text { Narasumber yang } \\
\text { memberikan pendapat } \\
\text { atau yang pendapatnya } \\
\text { diperlukan dalam } \\
\text { sebuah aktivitas. }\end{array}$ & Kranata \\
& $\begin{array}{c}\text { Memonitor kemajuan } \\
\text { informasi atas aktivitas } \\
\text { yang dilakukan. }\end{array}$ & 2 Orang \\
& \multicolumn{2}{|c|}{ Pustakawan } \\
\hline
\end{tabular}

\section{PEMBAHASAN}

Pada pembahasan ini, peneliti mengukur tingkat kematangan SLiMS pada Dinas Perpustakaan dan Kearsipan kota Salatiga berdasarkan hasil wawancara dan observasi bagian terkait pengguna Framework COBIT 4.1 domain ME. Penelitian ini berfokus pada 4 manajemen area yaitu proses monitor keperluan perusahaan dan sistem yang digunakan apakah sesuai standar, memastikan kontrol desain memenuhi syarat dan peraturan, serta melakukan proses pemantauan yang berhubungan dengan standar efektivitas sistem, serta kemampuan dalam mencapai tujuan bisnis oleh penilaian yang dilakukan secara mandiri. Wawancara pada penelitian ini berfokus pada proses ME Framework COBIT 4.1 dengan narasumber yaitu Dinas Perpustakaan dan Kearsipan kota Salatiga. Narasumber dipilih berdasarkan posisi, jabatan dan tanggung jawab yang berperan pada proses ME SLiMS.

\subsection{ME1 (Monitor and Evaluate IT Performance)}

Evaluasi kinerja TI pada aplikasi SLiMS Dinas Perpustakaan dan Kearsipan kota Salatiga dilakukan dengan proses pemetaan tujuan bisnis dan TI. Teknologi Informasi dan strategi Perpustakaan berdasarkan hasil penelitian telah berjalan dengan baik, namun ada beberapa kendala seperti yang disampaikan oleh Bapak Alwan Fauzan dari bagian pelayanan PERPUSDA Salatiga:

"Jadi dari dulu itu kita masih menggunakan SLiMS 7 untuk pengelolaan pelayanan perpustakaan dan itu sudah termasuk standar. Ada beberapa menu yang bisa mengakomodir kebutuhan pelayanan perpustakaan, tetapi sekarang ini suda direkomendasikan untuk menggunakan aplikasi INLISLite dari Perpustakaan Nasional, dan rencananya akan berpindah di Tahun 2022 ke aplikasi INISLite. Selama ini memang kinerja SLiMS termasuk baik, namun ada beberapa masalah teknis diluar aplikasi seperti server sering down atau listrik padam. Namun sudah bisa ditangani dengan di sediakan genset di kantor perpustakaan untuk menghidupkan listrik dan untuk masalah server down, sejauh ini kita pakai layanan secara manual yakni penulisan secara manual dan setelah listrik menyala dan server sudah kembali berfungsi dengan baik, kita memasukan data ke SLiMS.

Berdasarkan jawaban Bapak Alwan Fauzan dari bagian pelayanan Dinas Perpustakaan dan Kearsipan kota Salatiga, maka dapat disimpulkan bahwa kinerja TI telah sesuai standar. Hasil wawancara menunjukkan bahwa evaluasi Kinerja TI pada Dinas Perpustakaan dan Kearsipan kota Salatiga memiliki tingkat kematangan (maturity level) berdasarkan COBIT 4.1, berada ada pada level 2 (Repeatable but Intuitive).

\subsection{ME2 (Monitor and Evaluate Internal Controls)}

Proses monitoring dan evaluasi internal pada sistem aplikasi SLiMS pada Dinas Perpustakaan dan Kearsipan kota Salatiga bertujuan mengatur dan menjamin standar penilaian dan pengendalian internal, seperti yang disampaikan oleh Bapak Chandra Brian dari bagian pelayanan PERPUSDA Salatiga:

"Pengendalian internal dari server SLiMS sekarang telah dipakai pada kantor perpustakaan sendiri dan jika terjadi masalah terhadap server sudah bisa di kontrol secara langsung oleh pustakawan yang ada. Untuk mengakses SLiMS pengguna harus memiliki username dan password yang khusus dan hanya diketahui oleh penggunanya sendiri. Untuk pustakawan dibuat juga username dan password masing-masing dan untuk backup datanya dilakukan setiap minggu."

Hasil percakapan dengan Bapak Chandra Brian dari Dinas Perpustakaan dan Kearsipan kota Salatiga menyimpulkan bahwa proses pemantauan internal SLiMS menunjukkan bahwa hanya pengguna atau admin yang memiliki username dan password yang dapat mengakses SLiMS, sedangkan data akan terus di backup setiap minggu dengan tujuan menjaga kerahasiaan data ketika di perlukan. Berdasarkan penjelasan di atas maka dapat disimpulkan bahwa Dinas Perpustakaan dan Kearsipan kota Salatiga memiliki sistem pemantauan dan pengendalian internal yang mengelola dan menjaga standar pengoperasian sehingga tingkat kematangan (maturity level) berdasarkan COBIT 4.1, Dinas Perpustakaan dan Kearsipan Kota Salatiga berada pada level 3 (Defined Process).

\subsection{ME3 (Ensure Compliance External Requirements)}

Bapak Budi Santoso dari bagian pengelolaan PERPUSDA Salatiga menjelaskan tentang sistem monitoring dan evaluasi pada proses tingkat kematangan bisnis TI Dinas Perpustakaan dan Kearsipan Kota Salatiga. Beliau mengatakan bahwa:

"Untuk proses bisnis sendiri seperti yang saya bilang tadi menu-menu yang digunakan dalam aplikasi SLiMS telah memenuhi standar. Misalnya menu pendaftaran anggota, menu absensi kehadiran pengunjung, menu penelusuran atau koleksi, menu peminjaman dan pengembalian, menu perpanjangan buku yang di pinjam, serta menu untuk pelaporan buku yang di pinjam atau kelompok buku yang di pinjam dalam satu tahun atau 
dalam beberapa bulan, dan dalam sehari dapat dilihat pada aplikasi SLiMS. Untuk stock opname perhitungan koleksi juga bisa di lakukan di aplikasi SLiMS, jadi menurutu saya SLiMS telah memenuhi standar.'

Hasil wawancara bersama Bapak Budi Santoso dari Dinas Perpustakaan dan Kearsipan kota Salatiga maka dapat dikemukakan bahwa proses bisnis TI misalnya dalam proses perhitungan koleksi (stock opname) pada aplikasi SLiMS telah memenuhi standar. Dengan demikian maka dapat disimpulkan bahwa Dinas Perpustakaan dan Kearsipan kota Salatiga telah memiliki bisnis proses TI dengan tingkat kematangan (maturity level) berdasarkan COBIT4.1 berada pada level 2 (Repeatable but Intuitive).

\subsection{ME4 (Provide IT Governance)}

Tatakelola TI pada aplikasi SLiMS di Dinas Perpustakaan dan Kearsipan kota Salatiga, berdasarkan pihak SDM TI telah maksimal dan sesuai standar dalam mengoperasikan aplikasi SLiMS. Berhubungan dengan hal dimaksud, Bapak Budi Santoso dari bagian pengelolaan PERPUSDA Salatiga mengatakan bahwa:

"Sejauh ini penggunaan SLiMS cukup memuaskan dan tidak ada masalah. Sistem berjalan dengan lancar. Namun kami mengharapkan agar aplikasi SLiMS diperbarui sehingga ada peningkatan software karena saat ini kami masih menggunakan SLiMS 7. Kami berharap diperbarui ke versi 8 atau 9 atau pindah ke aplikasi INISLite. Tetapi sejauh ini aplikasi SLiMS cukup memuaskan dan bisa di kelola sendiri atau bisa di kembangkan sendiri misalnya kita bisa menambahkan menu WA gateway untuk mengirim WhattsApp via SliMS. Sejauh ini untuk SDM yang ${ }^{3}$ ada sudah kompeten meskipun kadang kami masih menemui kesulitan dalam perubahan coding. Namun kami bisa melakukan konsultasi ke komunitas SLiMS dan jika tingkat kesulitan serius kami biasanya akan meminta bantuan ke KOMINFO. Namun sejauh ini pengelola yang ada di Perpustakaan sudah bisa mengatasi atau sudah mampu untuk mengelola SLiMS mulai dari peraturan dan manajemen perpustakaan. Saat ini SLiMS bisa di akses dari luar perpustakaan jika pengguna ingin melakukan penelusuran buku."

Berdasarkan hasil diskusi dengan Bapak Budi Santoso dari Dinas Perpustakaan dan Kearsipan kota Salatiga maka dapat disimpulkan bahwa Tata kelola TI dan SDM pada PERPUSDA cukup maksimal dan memenuhi standar dalam dan kompeten dalam mengatasi risiko yang terjadi pada aplikasi SLiMS. Berdasarkan pendapat oleh Bapak Budi Santoso maka dapat dikemukakan bahwa Dinas Perpustakaan dan Kearsipan kota Salatiga mempunyai penerapan Tata kelola TI dan Sumber Daya Manusia yang cukup maksimal. Dengan demikian tingkat kematangan (maturity level) berdasarkan COBIT 4.1, Dinas Perpustakaan dan Kearsipan Kota Salatiga berada pada posisi level 4 (Managed and Measurable).
Pada gambar 3. Spider Chart tingkat kematangan menunjukkan bahwa ME1 (Monitor and Evaluate IT Performance) Dinas Perpustakaan dan Kearsipan kota Salatiga berada pada posisi kematangan level 2 (Repeatable but Intuitive).

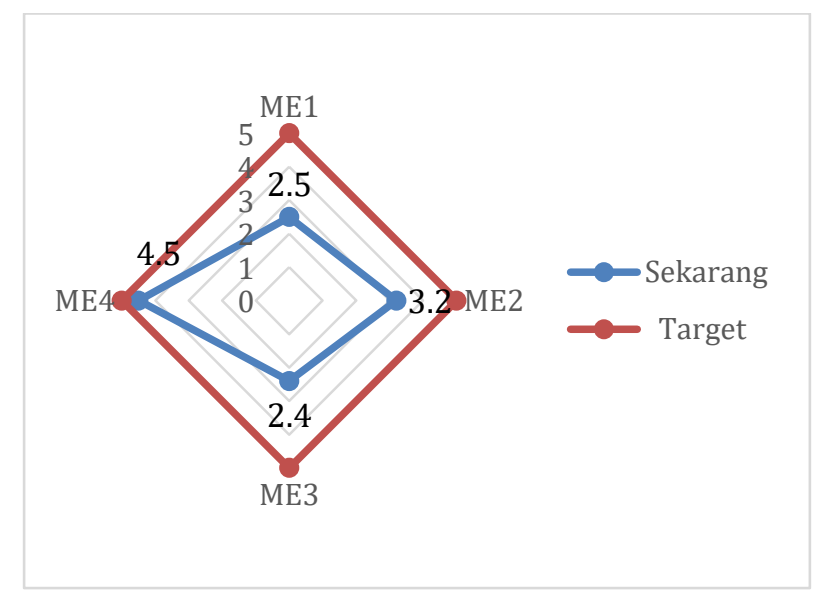

Gambar 3. Spider Chart Tingkat Kematangan

Pengelolaan sistem evaluasi kinerja IT pada aplikasi SLiMS di Dinas Perpustakaan dan Kearsipan Kota Salatiga, dilakukan menggunakan sistem teknologi informasi, Namun perpustakaan saat ini belum berjalan dengan baik. Hal ini dikarenakan ditemukan beberapa masalah dan risiko yang terjadi seperti listrik padam, dan server down. Dengan demikian pustakawan diharuskan untuk melakukan proses pelayanan sirkulasi secara manual yakni di tulis pada buku manual, dan setelah listrik beroperasi kembali dan jika aplikasi SLiMS sudah bisa di akses kembali, maka data manual akan di masukan ke dalam aplikasi SLiMS.

Dengan demikian sistem pengelolaan kontrol internal pada Dinas Perpustakaan dan Kearsipan kota Salatiga yakni ME2 (Monitor and Evaluate Internal Controls) berada pada tingkat kematangan level 3 (Defined Process). Hal ini berarti pengelolaan aplikasi SLiMS telah berjalan sesuai dengan rencana yang ditetapkan oleh organisasi, dimana setiap pengguna telah mempunyai akses untuk mengontrol datanya sendiri misalnya data peminjaman dan juga data karyawan yang disimpan secara online ke dalam database aplikasi SLiMS. Data pada aplikasi SLiMS selalu di backup setiap seminggu sekali dengan tujuan menjaga privasi dan keamanan data. Selanjutnya, aplikasi SLiMS yakni ME3 (Ensure Compliance External Requirements) saat ini telah berada pada tingkat kematangan level 2 (Repeatable but Intuitive). Hal ini berarti evaluasi proses bisnis Dinas Perpustakaan dan Kearsipan kota Salatiga telah berjalan dengan baik, memenuhi standar dan rencana strategis yang telah ditetapkan, contohnya aplikasi SLiMS saat ini telah memiliki menu pendaftaran anggota, peminjaman dan pengembalian buku, serta proses perhitungan koleksi (stock opname). Yang terakhir, aplikasi SLiMS Dinas Perpustakaan dan Kearsipan Kota 
Salatiga yakni ME4 (Provide IT Governance) berada pada tingkat kematangan level 4 (Managed and Measurable). Pengelolaan TI pada Dinas Perpustakaan dan Kearsipan Kota Salatiga, menggunakan aplikasi SLiMS cukup memenuhi standar dalam proses pelayanan sirkulasi. Di lain pihak, proses pembaharuan software yang lebih baik misalnya aplikasi INISLite, tetap diharapkan dan direkomendasikan untuk dapat direalisasikan karena saat ini Dinas Perpustakaan dan Kearsipan kota Salatiga masih menggunakan SLiMS 7. Selain itu, hal penting lainnya adalah Dinas Perpustakaan dan Kearsipan kota Salatiga telah memiliki sumber daya manusia yang memadai dan mampu untuk mengelola aplikasi SLiMS, dan juga dalam memberikan pelayanan kepada pelanggan PERPUSDA.

\subsection{Rekomendasi Proses TI}

Proses evaluasi dan audit yang dilakukan pada penelitian ini menggunakan Framework COBIT 4.1 menunjukkan bahwa terdapat beberapa masalah pada aplikasi SLiMS pada Dinas Perpustakaan dan Kearsipan Kota Salatiga yang belum memenuhi standar yang berlaku dalam domain $\mathrm{ME}$, melalui maturity model. Penelitian ini menemukan bahwa tingkat level kematangan dari aplikasi SLiMS berada pada kategori cukup memadai. Dapat dilihat pada tabel 2, peneliti merekomendasikan agar setiap permasalahan yang terjadi pada aplikasi SLiMS dapat menggunakan domain ME sebagai alat ukur. Hasil dari penelitian juga dapat digunakan sebagai bahan acuan dalam mencapai target yang diinginkan oleh PERPUSDA Salatiga.

\section{Tabel 2. Domain ME Permasalahan \& Rekomendasi}

\begin{tabular}{|l|l|l|}
\hline Domain ME & Permasalahan & Rekomendasi \\
\hline $\begin{array}{l}\text { ME1 (Monitor } \\
\text { dan Evaluasi }\end{array}$ & $\begin{array}{l}\text { Ditemukan kekurangan dalam pengoperasian } \\
\text { aplikasi yang diakibatkan oleh banyaknya pegawai } \\
\text { yang tidak dapat mengoperasikan aplikasi SLiMS } \\
\text { dengan baik. Hal ini dikarenakan kurangnya } \\
\text { pelatihan aplikasi SLiMS untuk para staff dan } \\
\text { pegawai. }\end{array}$ & $\begin{array}{l}\text { Pelatihan khusus bagi para staff dan pegawai } \\
\text { tentang bagaimana mengoperasikan aplikasi } \\
\text { SLiMS pada Dinas Perpustakaan dan Kearsipan } \\
\text { kota Salatiga. }\end{array}$ \\
\hline $\begin{array}{l}\text { ME2 (Monitor } \\
\text { dan Evaluasi } \\
\text { Control Internal) }\end{array}$ & $\begin{array}{l}\text { Ditemukan bahwa proses ME2 hanya dilakukan } \\
\text { pada infrastruktur TI. Belum ada pengawasan } \\
\text { khusus terhadap penggunaan TI dan aplikasi SLiMS }\end{array}$ & $\begin{array}{l}\text { Diperlukan peningkatan dalam hal pengawasan } \\
\text { terhadap infrastruktur TI dan penggunaan aplikasi } \\
\text { SLiMS }\end{array}$ \\
\hline $\begin{array}{l}\text { ME3 } \\
\text { Jendapatkan }\end{array}$ & $\begin{array}{l}\text { Ditemukan bahwa belum ada kebijakan penerapan } \\
\text { TI. Namun telah dilakukan pendekatan untuk } \\
\text { mengarahkan tujuan penerapan TI. Sayangnya } \\
\text { Independent) }\end{array}$ & $\begin{array}{l}\text { Perlu adanya penyusunan dan pengelolaan } \\
\text { kebijakan penerapan TI berdasarkan standar SOP } \\
\text { yang berlaku dan juga mengadakan pengarahan } \\
\text { yang jelas dalam mengelola dan mengevaluasi } \\
\text { proses bisnis di Dinas Perpustakaan dan } \\
\text { Kearsipan Kota Salatiga. }\end{array}$ \\
\hline $\begin{array}{l}\text { ME4 (Penyediaan } \\
\text { Untuk Tata kelola } \\
\text { TI) }\end{array}$ & $\begin{array}{l}\text { Dinas Perpustakaan dan Kearsipan kota Salatiga } \\
\text { hingga saat ini masih menggunakan aplikasi SLiMS } \\
\text { versi 7, dan belum ada pembaharuan dari aplikasi } \\
\text { tersebut ke versi yang terbaru. }\end{array}$ & $\begin{array}{l}\text { Perlu adanya pengembangan software ke versi } \\
\text { yang lebih terbaru atau pindah ke aplikasi } \\
\text { rekomendasi dari Perpustakaan Nasional yaitu } \\
\text { aplikasi INISLite. }\end{array}$ \\
\hline
\end{tabular}

\section{KESIMPULAN}

Penelitian ini menemukan bahwa Sistem Audit Informasi pada pelayanan Dinas Perpustakaan dan Kearsipan kota Salatiga menggunakan Framework COBIT 4.1 domain Monitor and Evaluate. Proses wawancara dengan staff dari Dinas Perpustakaan dan Kearsipan kota Salatiga, bertujuan mengevaluasi dan menganalisis tingkat kematangan (Capability Level) aplikasi SLiMS, serta mengevaluasi kesesuaian domain ME pada proses bisnis TI yang diterapkan pada kinerja Sistem Informasi Pelayanan Dinas Perpustakaan dan Kearsipan Kota Salatiga. Data yang diperoleh menunjukkan bahwa tingkat kematangan domain $\mathrm{ME}$ pada aplikasi SLiMS bervariasi. Penelitian ini menunjukkan bahwa ME1 (Monitor dan Evaluasi Kinerja IT) pada aplikasi SLiMS, berada pada tingkat kematangan level 2,5 (Repeatable but Intuitive). Penelitian ini juga menemukan bahwa pada dasarnya semua prosedur aplikasi SLiMS telah dijalankan sesuai standar. Namun, standar prosedur dan tanggung jawaban hanya terletak pada masing-masing pengguna aplikasi
SLiMS. Selanjutnya, penelitian ini juga menemukan bahwa aplikasi SLiMS untuk kategori ME2 (Monitor dan Evaluasi Control Internal), berada pada tingkat kematangan level 3,2 (Defined Process) yang mana proses tersebut bertujuan untuk mengendalikan dan mengontrol keamanan data dan akses yang ada pada aplikasi SLiMS. Sedangkan untuk kategori ME3 (Mendapatkan Jaminan Independent), aplikasi SLiMS berada pada tingkat kematangan level 2,5 (Repeatable but Intuitive). Penelitian ini menemukan bahwa aplikasi SLiMS telah mengikuti prosedur yang berlaku, dimana tanggung jawab data berada hanya pada masing masing individu pengguna aplikasi SLiMS. Selanjutnya, pada kategori ME4 (Penyediaan Untuk Tata kelola TI), aplikasi SLiMS telah berada pada tingkat kematangan level 4,5 (Managed and Measurable). Pada level ini, proses bisnis TI pada aplikasi SLiMS dipantau dan dievaluasi. 


\section{SARAN}

Hasil penelitian menunjukkan bahwa Dinas Perpustakaan dan Kearsipan kota Salatiga diharapkan untuk meningkatkan sistem evaluasi dan kontrol yang efektif dalam proses penggunaan dan pengelolaan aplikasi SLiMS. Selanjutnya berdasarkan hasil penelitian, disarankan agar Dinas Perpustakaan dan Kearsipan kota Salatiga dalam melakukan peningkatan kapasitas pada semua karyawan dalam rangka meningkatkan kemampuan karyawan dalam mengoperasikan aplikasi SLiMS.

\section{DAFTAR PUSTAKA}

Andry, J. F. $d k k$. 2018 'Penggunaan COBIT 4. 1 Dengan Domain ME Pada Sistem Informasi Absensi ( Studi Kasus: Universitas XYZ )', Informatika Mulawarman: Jurnal Ilmiah Ilmu Komputer Vol. 13, No. 2 September 2018 e-ISSN 2597-4963 dan pISSN1858-4853, 13(2). doi: http://dx.doi.org/10.30872/jim.v13i2.1152

Informatika.

Asyari, M. D. S. and Triana, Y. S. 2018 'Credit Analysis Tool System Application Using Cobit 4.1 Method Approach', International Journal of Computer Science and Mobile Computing, 7(4), pp. 153-165. Available

at:

https://ijcsmc.com/docs/papers/April2018/V7I4201 826.pdf.

Azizah, N. 2017 'Audit Sistem Informasi Menggunakan Framework COBIT 4.1 Pada E-Learning Uninsu Jepara', Jurnal SIMETRIS, Vol 8 No 1 April 2017 ISSN: 2252-4983, 8(1), pp. 377-382.

Haullusy, C. A. F. and Manuputty, A. D. 2019 'Audit Sistem Informasi Pelayanan Menggunakan Framework Cobit 4. 1 ( Studi Kasus: Dinas Perpustakaan dan Kearsipan Kota Salatiga )', DOI : https://repository.uksw.edu/bitstream/123456789/1 9581/2/T1_682013069_Full\%20text.pdf (diakses tanggal $4 \mathrm{Mei}$ 2021), 1, p. 10. doi: Https://Repository.Uksw.Edu/Bitstream/123456789 /19581/2/T1_682013069_Full\%20text.Pdf.

Jourdano, G. V. dkk. 2018 'Audit Sistem Informasi Menggunakan Framework COBIT 4. 1 ( Dengan Domain Monitor and Evaluate ) Pada PT. Samudera Indonesia Tbk', jurnal INFRA Vol 6, No 1 (2018), 1.

Kurniawan, R., Yohanes, A. and Wijaya, A. (2018) 'Audit Aplikasi Medico Menggunakan Framework COBIT 4.1 Domain ME', Jurnal TEKNOINFO, Vol. 12, No. 2, 2018, 38-42, ISSN 2615-224X AUDIT, 12(2), pp. 38-42.

Maghfiroh, I., Murahartawaty, M. and Mulyana, R. 2016 'Analisis Dan Perancangan Tata Kelola Ti Menggunakan Cobit 4.1 Domain Deliver and Support (Ds) Pt Xyz', Jurnal Sistem Informasi, 12(1), p. 49. doi: 10.21609/jsi.v12i1.467.

Marzuki, K., Setyanto, A. and Nasiri, A. 2018 'Audit
Tata Kelola Teknologi Informasi Menggunakan Cobit 4. 1 Domain Monitoring Evaluasi Pada Perguruan Tinggi Swasta', Seminar Nasional Sistem Informasi dan Teknologi Informasi, pp. 412416.

Muhammad, J. R., A. 2021 'Audit Sistem Informasi Menggunakan Kerangka Kerja COBIT 4.1 Pada Siix Electronics Indonesia', JURNAL COMASIE VOL. 04 NO. 04 (2021), 04.

Prasanti, D. 2018 'Penggunaan Media Komunikasi Bagi Remaja Perempuan Dalam Pencarian Informasi Kesehatan', LONTAR: Jurnal Ilmu Komunikasi, 6(1), pp. 13-21. doi: 10.30656/lontar.v6i1.645.

Rahayu, A. S. and Wijaya, A. F. 2020 'Evaluasi Konerja Teknologi Informasi Berdasarkan Domain ME Menggunkan COBIT 4.1 (Studi Kasus : PT. Global Infotech Solution)', Jurnal Bina Komputer JBK, Vol. 2, No. 1, Februari 2020: 44-51 EVALUASI, 2(1), pp. 44-51.

Rumere, H. M., Tanaamah, A. R. and Sitokdana, M. N. N. 2020 'Analisis Kinerja Tata Kelola Teknologi Informasi Pada Dinas Perpustakaan dan Kearsipan Daerah Kota Salatiga Menggunakan Framework COBIT 5.0', SEBATIK 2621-O69X VOL 24 NO 1 (2020): JUNI 2020, pp. 14-21.

Styo, D. $d k k .2021$ 'Evaluasi Sistem Informasi Manajemen Puskesmas ( Simpus) ( Studi Kasus: Puskesmas Induk Di Wilayah Kabupaten Sukoharjo )', Jurnal TIKomSiN, Vol. 9, No. 1, April 2021 ISSN Online: 2620-7532, 9(1). doi: DOI: https://doi.org/10.30646/tikomsin.v9i1.541.

Susilowati 2017 'Kegiatan Humas Indonesia Bergerak Di Kantor Pos Depok II Dalam Meningkatkan Citra Instansi Pada Publik Eksternal', Jurnal Komunikasi, VIII(2), pp. 47-54.

Taslihudin, A. B. 2016 'Audit Siste Informasi Pada Sistem Admisi UIN Sunan Kalijaga Yogyakarta Menggunakan Framework COBIT 4.1', Resma, $3(2), \quad$ pp. 13-22. doi: http://repository.unissula.ac.id/11683/3/DAFTAR\% 20PUSTAKA.pdf.

Wahono, B. B. 2015 'Perancangan Tatakelola Teknologi Informasi Untuk Peningkatan Layanan Sistem Informasi Kesehatan (Studi Kasus Dinas Kesehatan Kabupaten Jepara)', Simetris : Jurnal Teknik Mesin, Elektro dan Ilmu Komputer, 6(1), p. 101. doi: 10.24176/simet.v6i1.244. 